\title{
A New Class of Monoamine Oxidase Inhibitors
}

\author{
R. R. Vunnam, D. Bond, R. A. Schatz, N. S. Radin, and N. Narasimhachari*
}

\begin{abstract}
Newly synthesized compounds have been found to inhibit mitochondrial monoamine oxidase (MAO) in mouse brain and rat liver. A series of 2-acylamino-3-tert-aminopropiophenones acted preferentially against MAO type B (2-phenylethylamine as substrate), apparently irreversibly. 2Decanoylamino-3-morpholinopropiophenone acted similarly in vivo toward the cerebral MAO, producing a dose-related inhibition. At high dose levels, MAO type A was also severely inhibited. The effects were produced rapidly and restoration of enzyme activity also appeared rapidly. The half-life for MAO type A could be estimated from the rate of enzyme reappearance to be $13 \mathrm{~h}$. It is suggested that the amino ketones undergo a $\beta$-elimination reaction at the enzyme's active site, forming a reactive species (an $\alpha, \beta$-unsaturated ketone), which reacts covalently with a nucleophilic group of the enzyme by a Michael addition. Some other related compounds, derivatives of phenylpropane, also showed inhibitory activity against $\mathrm{MAO}$, particularly against type A (serotonin as substrate). The morpholino compound might have promise as a quickly effective, short-acting inhibitor of MAO type B. Key words: Monoamine oxidase inhibitors-Monoamine oxidase type B-2-Decanoylamino - 3 morpholinopropiophenone-Monoamine oxidase half-life.
\end{abstract}

In the course of an attempt to develop inhibitors of glucocerebroside synthetase, analogs of ceramide were synthesized and evaluated with an in vitro assay. When some of the compounds were injected into mice, symptoms such as head twitches, tremor, and abduction of the hind legs were produced, indicating that these compounds have CNS effects. Subsequent tests for effects on monoamine oxidase [EC 1.4.3.4, amine:oxygen oxidoreductase (deaminating) (flavine containing)] showed that they exhibited appreciable inhibitory activity. Since some of the compounds constituted a new class of inhibitors of this enzyme, we made a more detailed study of their effects on monoamine oxidase (MAO) in rodent liver and brain, with special emphasis on the question of differential sensitivity toward the two types of enzyme, A and B (Johnston, 1968; Neff et al., 1974). It is currently of considerable interest to determine whether selective inhibition of the two types would be clinically useful in the treatment of human disorders, neurological, behavioral, or circulatory.

\section{MATERIALS AND METHODS}

2-( $N$-acylamino $)-3$-substituted aminopropiophenones were prepared from 2-amino-acetophenone (Wolfheim, 1914) by acylation, followed by a Mannich reaction with paraformaldehyde and a secondary amine in the presence of $\mathrm{HCl}$. For example, the acetyl compound (RV-433) was made by dissolving $2.2 \mathrm{~g}(12.5 \mathrm{mmol})$ of 2 acetaminoacetophenone (Wolfheim, 1914), $0.5 \mathrm{~g}$ (5.5 $\mathrm{mmol})$ of paraformaldehyde, and $1.5 \mathrm{ml}(17.2 \mathrm{mmol}) \mathrm{mor}$ pholine in $15 \mathrm{ml}$ ethanol and adding $0.3 \mathrm{ml}$ of concentrated $\mathrm{HCl}$. The mixture was refluxed for $15 \mathrm{~h}$; then, about $10 \mathrm{ml}$ of the solvent were removed with a rotary vacuum evaporator. The mixture was diluted with $30 \mathrm{ml}$ of water and adjusted with $\mathrm{HCl}$ to $\mathrm{pH} \mathrm{3}$, and nonbasic impurities were removed by extracting with $45 \mathrm{ml}$ of ether. The remaining material was made alkaline with ammonium hydroxide and the free base was extracted into $2 \times 30 \mathrm{ml}$ of
From the Mental Health Research Institute (Department of Psychiatry), University of Michigan, Ann Arbor, Michigan 48109; and the *Department of Psychiatry, Medical College of Virginia, Richmond, Virginia 23298. Address reprint requests to Dr. Norman Radin, 1103 E. Huron, Ann Arbor, Michigan 48109.
Received March 14, 1979; accepted August 16, 1979.

Abbreviations used: 5-HT, Serotonin; MAO, Monoamine oxidase; PEA, Phenethylamine, or 2-phenylethylamine. 
ethyl acetate. The pooled extracts were washed with saline and dried with $\mathrm{Na}_{2} \mathrm{SO}_{4}$, and the solvent was removed. The amine was converted to a crystalline salt by dissolving it in $10 \mathrm{ml}$ of EtOAc and adding $2.3 \mathrm{~g} \mathrm{(12} \mathrm{mmol)}$ of $p$-toluenesulfonic acid hydrate in EtOAc. The resultant precipitate was crystallized twice from methanol. The yield was $72 \%(4 \mathrm{~g})$, m.p. $191-2^{\circ} \mathrm{C}$.

Analysis: $\mathrm{C}_{1,5} \mathrm{H}_{20} \mathrm{~N}_{22} \mathrm{O}_{3,3} \cdot \mathrm{C}_{7} \mathrm{H}_{8} \mathrm{O}_{3,3} \mathrm{~S}$ (mol. wt. 448.5). Calculated, $58.92 \% \mathrm{C}$ (found 58.83$), 6.29 \% \mathrm{H}(6.18), 6.25 \% \mathrm{~N}$ (6.24). 2-Decanoylamino-3-morpholinopropiophenone (RV-378) was prepared similarly from 2 -decanoylaminoacetophenone (m.p. $79-80^{\circ} \mathrm{C}$, from benzene-hexane) but isolated as the hydrochloride (yield $62 \%$, m.p. $137-8^{\circ} \mathrm{C}$ from $\mathrm{EtOAc}$ ).

Analysis: $\mathrm{C}_{233} \mathrm{H}_{36} \mathrm{~N}_{2} \mathrm{O}_{3 .} \cdot \mathrm{HCl}$ (mol. wt. 425.0). Calculated, $65.00 \% \mathrm{C}$ (found 65.13$), 8.78 \% \mathrm{H}(8.82), 6.59 \% \mathrm{~N}$ (6.52).

The piperidine analogue of RV-378 (RV-471) was also prepared: 2 - decanoylamino - 3 - piperidinopropiophenone toluenesulfonic acid salt (yield, $30 \%$, m.p. $87-9^{\circ} \mathrm{C}$ from EtOAc). On drying over $\mathrm{P}_{2} \mathrm{O}_{5}$ in vacuum at $23^{\circ} \mathrm{C}$ it became hygroscopic and gave an analysis indicating the presence of one molecule of water.

Analysis: $\mathrm{C}_{31} \mathrm{H}_{46} \mathrm{~N}_{2} \mathrm{O}_{6 i} \mathrm{~S} . \mathrm{H}_{2} \mathrm{O}$ (mol. wt. 576.8). Calculated: $64.56 \% \mathrm{C}$ (found 64.97$), 8.39 \% \mathrm{H}(8.64), 4.86 \% \mathrm{~N}$ (4.97).

2-Decanoylamino-3-morpholino-1-phenyl-1-propanol

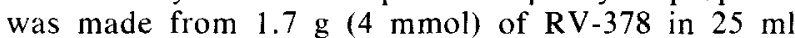
methanol. To this was added $1.1 \mathrm{~g}$ of $\mathrm{K}_{2} \mathrm{CO}_{33}$ in $2 \mathrm{ml}$ water, followed by $0.8 \mathrm{~g}$ of $\mathrm{NaBH}_{4}$ in small portions over a 30min period. After $3 \mathrm{~h}$ of stirring, most of the solvent was removed in vacuo and the residue was shaken with $10 \mathrm{ml}$ of water and $75 \mathrm{ml}$ of EtOAc. The organic phase was washed with $10 \%$ salt, dried over $\mathrm{Na}_{2} \mathrm{SO}_{4}$, and the solvent removed. The amine was converted to the hydrochloride with $\mathrm{HCl}$ in isopropanol, evaporated to dryness, and triturated with ether. The product (RV-538b) melted at $107-113^{\circ} \mathrm{C}$ after crystallization from chloroform-ether; yield, $1.5 \mathrm{~g}$. Silica gel TLC with chloroform-methanol, 95:5 (v/v), revealed two spots very close to each other, indicating that the reduction yielded the threo- and erythro-isomers. For elemental analysis, the salt was recrystallized from EtOAc, converted to the free base with $\mathrm{NaHCO}_{3}$, and purified with a silica gel column, using chloroform/methanol/ammonium hydroxide (concd.) 96:4:0.5 and 94:6:0.5 (by vol.). The melting point was $96-7^{\circ} \mathrm{C}$ (from hexane). This material (RV-538a) showed only the faster-moving spot with TLC.

Analysis: $\mathrm{C}_{23} \mathrm{H}_{38} \mathrm{~N}_{2} \mathrm{O}_{33}$ (mol. wt. 390.6). Calculated, $70.73 \% \mathrm{C}$ (found 70.76$), 9.81 \% \mathrm{H}(9.74), 7.17 \% \mathrm{~N}(7.13)$.

The infrared spectra of the compounds were obtained with the $\mathrm{KBr}$ pellet technique. The expected two carbonyl bands were seen in the case of the keto amides, at about 5.94 and $6.05 \mu \mathrm{m}$. The reduced ketone (RV-538) showed only the amide $\mathrm{C}=\mathrm{O}$ band at $6.05 \mu \mathrm{m}$.

The preparation of other compounds tested in this study has been reported (Hyun et al., 1975) or will be reported separately.

Adult mice (Swiss-Webster, 25-30 g) from Charles River Laboratories were used. For whole homogenate studies, brains were homogenized in 5-10 volumes of 50 mm-potassium phosphate, $\mathrm{pH}$ 7.4. Mitochondria were prepared by homogenizing brain in 4 vol. of $0.32 \mathrm{M}$ sucrose, centrifuging at $700 \mathrm{~g}$ for $15 \mathrm{~min}$, washing the pellet, and centrifuging the combined washings at 20,000 $g$ for $30 \mathrm{~min}$. The mitochondrial pellet was washed with sucrose and suspended in buffer as above. Monoamine oxidase was determined in the brain preparations with 0.1 mM-5-HT (serotonin) or PEA (phenethylamine) as substrates (Owen et al., 1977).

Rat liver mitochondria were prepared similarly (Hogeboom, 1955) and tested with $35 \mu \mathrm{M}-\left[{ }^{14} \mathrm{C} \mid\right.$ tyramine as substrate, in $0.2 \mathrm{M}$-phosphate, $\mathrm{pH} 7.4$.

The inhibitors were tested by evaporating a solution to dryness in each test tube or adding freshly prepared aqueous solutions. Protein was determined with modified Folin reagent (Lowry et al., 1951).

\section{RESULTS}

A survey of various related compounds in tests with brain MAO (Table 1) showed that some compounds were preferentially active against MAO type A (RV-83 and 125) and some were preferentially active against MAO type B (RV-378, 470, 471, 472). A compound not shown in the table, RV-252 ( $N$-[n-decyl] $-N^{\prime}-p$-methoxyphenyl guanidine), was rather active at $0.2 \mathrm{~mm}$ against both types of MAO: $55 \%$ inhibition against 5-HT oxidation and $36 \%$ against PEA oxidation. The corresponding values obtained without preincubating the inhibitor were not much different: $61 \%$ and $28 \%$. With some compounds, particularly the ketones, adding the substrate at the same time as the inhibitor reduced the inhibitory effect. The importance of the carbonyl group adjacent to the phenyl ring was shown by the drastically decreased inhibitory activity of the reduced compound (RV-378 versus 538).

Compounds RV-472 and 470 proved difficult to purify and were not studied in detail. They were not as selective as the other keto amines with respect to inhibition of the different types of MAO. Toluenesulfonic acid, used to prepare some of the amines in crystalline form, was not itself inhibitory to MAO.

The degree of inhibition by the keto amines on MAO type B resulting from preincubation with brain mitochondria was found to increase with duration of exposure to the inhibitor (Fig. 1). This indicates that the inhibitors acted by causing inactivation of the enzyme. The disappearance of enzyme activity was rapid at first, then slowed somewhat. Note the lack of a lag period, indicating that the inhibition was due to the added compound, not to a metabolically produced derivative of the inhibitor.

Evidence for the irreversibility of the inhibitory action of the keto amines was obtained (Table 2) by dialyzing the mitochondria after preincubating them with the inhibitors. Dialysis prior to incubating the preparation with substrate, which should have led to the removal of the inhibitor, did not restore the activity of the enzyme.

Tyramine is considered a nonselective substrate for types A and B MAO (Neff et al., 1974). When this substrate was used with rat liver mitochondria, 
TABLE 1. Inhibition of mouse brain monoamine oxidases by 2-decanoylamino3-morpholinopropiophenone and related compounds<smiles>[R]c1ccc([X]C([R])[R])cc1</smiles>

\begin{tabular}{|c|c|c|c|c|c|c|c|c|}
\hline \multirow{2}{*}{$\begin{array}{l}\text { Compound } \\
\text { number }\end{array}$} & \multirow{2}{*}{$\mathrm{X}$} & \multirow{2}{*}{$\mathrm{R}$} & \multirow{2}{*}{$\mathrm{R}^{\prime}$} & \multirow{2}{*}{$\mathrm{R}^{\prime \prime}$} & \multicolumn{4}{|c|}{ Percent Inhibition } \\
\hline & & & & & Sero & onin & Phene & hylamine \\
\hline $\mathrm{RV}-378$ & $C=0$ & $\mathrm{H}$ & $-\mathrm{NHCOC}_{9} \mathrm{H}_{19}$ & $-\mathrm{CH}_{2} \mathrm{I}$ & 6 & (8) & 51 & (15) \\
\hline$R V-471$ & $"$ & $"$ & $"$ & $-\mathrm{CH}_{2}$ & 8 & (8) & 71 & (9) \\
\hline$R V-472$ & $"$ & $"$ & $" 1$ & $-\mathrm{CH}_{2} \mathrm{~N}$ & 19 & (22) & 63 & (33) \\
\hline$R V-470$ & $"$ & $"$ & $"$ & $-\mathrm{CH}_{2} \mathrm{~N}(\mathrm{Me}) \mathrm{C}_{2} \mathrm{H}_{4} \mathrm{OH}$ & 30 & (15) & 58 & $(46)$ \\
\hline$R V-538 b$ & $\mathrm{CHOH}$ & $"$ & $"$ & $-\mathrm{CH}_{2}$ & 9 & - & 9 & (11) \\
\hline$R V-128$ & $" 1$ & $"$ & $"$ & $-\mathrm{CONHNH}_{2}$ & 35 & (0) & - & (3) \\
\hline$R V-83$ & CHNHC $_{10} \mathrm{H}_{21}$ & $1 "$ & $\mathrm{OH}$ & $-\mathrm{CH}_{2} \mathrm{OH}$ & 41 & $(56)$ & 28 & (23) \\
\hline$R V-218$ & $\mathrm{CHOH}$ & $\mathrm{NO}_{2}$ & $-\mathrm{NHC}_{10} \mathrm{H}_{21}$ & $"$ & 12 & - & - & - \\
\hline $\mathrm{RV}-125$ & $"$ & $\mathrm{NH}_{2}$ & " & 11 & 31 & (27) & 20 & $(27)$ \\
\hline$R V-143$ & $"$ & $\mathrm{H}$ & $"$ & $-\mathrm{CH}_{2} \mathrm{NH}_{2}$ & 7 & $(0)$ & 31 & $(38)$ \\
\hline
\end{tabular}

All compounds were tested at $0.1 \mathrm{~mm}$ except the last five $(0.2 \mathrm{~mm})$ with mitochondria and substrates at $0.1 \mathrm{~mm}$. The values shown are for the degree of inhibition obtained when the inhibitors were incubated for $30 \mathrm{~min}$ with the mitochondria before addition of substrate and incubation for $30 \mathrm{~min}$ more. The values in parentheses were obtained when the inhibitor was added together with the substrate. Compounds 378,470 , and 538 were hydrochlorides, 471,218 , and 143 were toluenesulfonates, 472 was a citrate, and 83 was the hydrobromide. The control MAO activity (in $\mathrm{nmol} / \mathrm{mg}$ protein/h) was 27.4 for 5 - $\mathrm{HT}$ and 22.4 for PEA.

the keto amines were found to be much more effective inhibitors than they were in mouse brain tested with PEA or 5-HT (Table 3). All the keto amines showed rather similar inhibitory power, except for RV-433, a homologue of the decanoylamino morpholine derivative in which the acyl group was acetyl instead of decanoyl. Evidently, a lipoidal side chain in the amide position produces more effective inhibition. By way of comparison, we found $50 \%$ inhibition of tyramine deamination with $0.1 \mu \mathrm{M}$ phenelzine, a clinically useful MAO inhibitor.

Intraperitoneal injection of mice with isotonic saline $(10 \mathrm{ml} / \mathrm{kg})$ or with RV-378 in saline, followed by sacrifice $2 \mathrm{~h}$ later, showed that the compound inhibited cerebral MAO in vivo (Fig. 2). At the lowest dosage level tested $(25 \mathrm{mg} / \mathrm{kg})$, type B MAO in brain was inhibited to a greater extent than was type A $(35 \%$ versus $12 \%)$. As the dosage was increased, this difference decreased.

A similar in vivo study with a dose level of 250 $\mathrm{mg} / \mathrm{kg}$ of RV-378 showed that the two types of MAO in brain were largely inactivated within $1 \mathrm{~h}$ (Fig. 3). Resynthesis (or reactivation) of MAO type A (the upper curve) became noticeable promptly after the minimum was reached, and the level of enzyme was almost back to normal within $24 \mathrm{~h}$. The rate of synthesis or reactivation of MAO type B (lower curve) was apparently slower. The reappearance of functional MAO molecules soon after the first hour following injection indicates that the inhibitor was rapidly destroyed, sequestered, or excreted.

Additional evidence for the rapid loss of inhibitor 


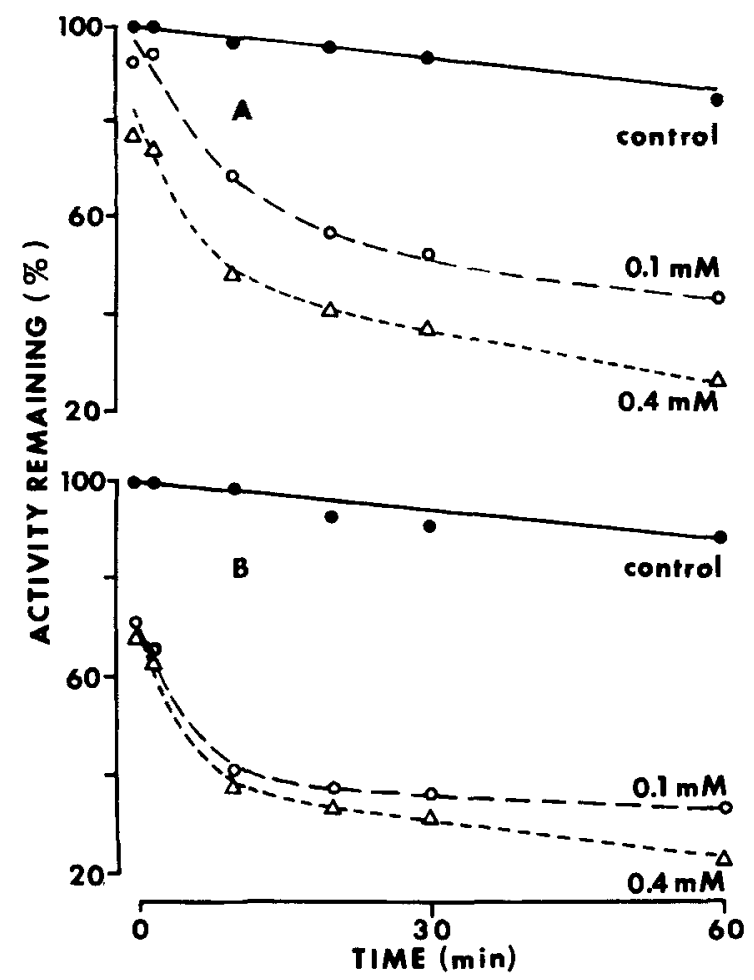

FIG. 1. Effect of preincubating mouse brain MAO for different lengths of time with RV-378 (A) and RV-471 (B). The in hibitors were preincubated with mitochondria for the indicated times at the indicated concentrations; then the preparations were tested for MAO activity with $0.1 \mathrm{mM} P E A$. The control MAO activity was $21.5 \mathrm{nmol} / \mathrm{mg}$ protein $/ \mathrm{h}$.

was obtained by assaying mixtures of brain homogenate from control and from drug-treated mice (Table 4). The brain homogenates from mice sacrificed 1 or $2 \mathrm{~h}$ after injecting RV-378 were mixed with an equal amount of the control brain homogenates and then assayed for MAO activity with PEA and 5-HT. The expected (mean) value was obtained with PEA, indicating that no free inhibitor remained in the drug-treated animals. In the case of 5-HT assays, the specific activity of the mixed tissues was even higher than expected.

TABLE 2. Activity of monoamine oxidase (type B) in dialyzed and undialyzed mouse brain mitochondria pretreated with inhibitor

\begin{tabular}{lcc}
\hline \multicolumn{1}{c}{ Inhibitor } & $\begin{array}{c}\text { Dialyzed enzyme } \\
\text { (nmol/h/mg protein) }\end{array}$ & $\begin{array}{c}\text { Undialyzed enzyme } \\
\text { (nmol/h/mg protein) }\end{array}$ \\
\hline None & 25.1 & 21.7 \\
RV-378 & $6.4(75)$ & $7.8(64)$ \\
RV-471 & $7.2(71)$ & $7.8(64)$ \\
\hline
\end{tabular}

Mitochondria were incubated for $30 \mathrm{~min}$ with inhibitor at $0.1 \mathrm{~mm}$, then assayed directly or dialyzed overnight against two changes of $5 \mathrm{~mm}$-potassium phosphate, $\mathrm{pH}$ 7.4. MAO type $B$ was assayed with $0.1 \mathrm{~mm}-\mathrm{PEA}$ as substrate. The numbers in parentheses indicate the degree of inhibition (percent) compared with the mitochondria that had not been treated with inhibitor.
TABLE 3. Inhibition of rat liver monoamine oxidas' by 2-decanoylamino-3-morpholinopropiophenone and related componnds

\begin{tabular}{llc}
\hline \multicolumn{1}{c}{ Inhibitor } & \multicolumn{1}{c}{$\begin{array}{c}\text { Basic moiety } \\
\text { in 3-position }\end{array}$} & $\begin{array}{c}\text { Concentration of amine } \\
\text { for 50\% inhibition }(\mu \mathrm{M})\end{array}$ \\
\hline RV-378 & morpholine & 3.5 \\
RV-471 & piperidine & 3.3 \\
RV-472 & N-Me-piperazine & 3.5 \\
RV-470 & N-Me-ethanolamine & 3.2 \\
RV-433" & morpholine" & 65 \\
RV-538a" & morpholine" & $>80$ \\
\hline
\end{tabular}

Rat liver mitochondria were preincubated with varying concentrations of inhibitor and then assayed with $35 \mu \mathrm{M}$-tyramine; the $\mathrm{IC}_{50}$ level was determined from the graphed data.

"This is the acetyl homolog of RV-378; " the reduced version of RV-378.

\section{DISCUSSION}

4-Morpholinobutyrophenone (NSD 2023) is known to be a MAO inhibitor (Squires and Lassen, 1968; Christmas et al., 1972). The latter study showed that the drug produced preferential inactivation of the type A enzyme in brain (5-HT and benzylamine as substrates) after oral administration to rats. Our most active compounds showed preferential action on the type B enzyme, which may be due to their having one less carbon atom in the aliphatic side chain and a long hydrophobic acylamino group between the ketonic and basic groups.

Although the concentration required for strong

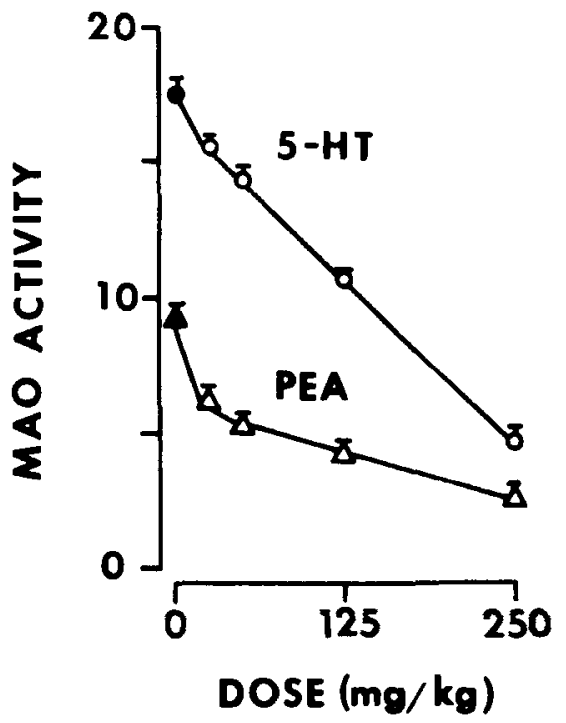

FIG. 2. Effect of varying doses of RV-378 on mouse brain MAO activity. Mice were injected intraperitoneally with saline $(10 \mathrm{ml} / \mathrm{kg})$ or the indicated dose of inhibitor and killed $2 \mathrm{~h}$ later. Enzyme activity was determined in mouse brain homogenates using $0.1 \mathrm{mM}-\mathrm{PEA}$ or $5-\mathrm{HT}$. Each point represents the mean activity $(\mathrm{nmol} / \mathrm{mg}$ protein $/ \mathrm{h}) \pm S . E . M$. of five mice. The open symbols denote a significant difference compared with saline-treated mice at the 0.001 level (Student's $t$-test). 


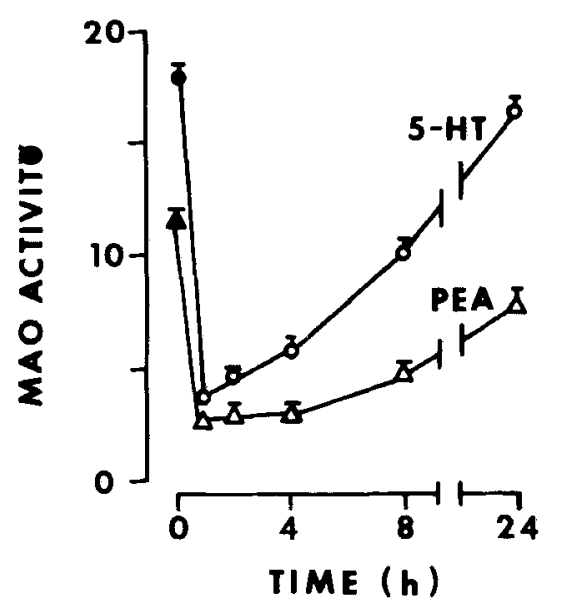

FIG. 3. Time course of MAO inhibition after treatment of mice with RV-378. Mice were injected as in Fig. $2(250 \mathrm{mg} / \mathrm{kg})$ and sacrificed at the times indicated. Enzyme activity was determined in brain homogenates with PEA or 5-HT. Each point represents the mean activity \pm S.E.M. of five to nine mice. Open symbols denote a significant difference compared with the saline-treated controls at the 0.001 level.

inhibition in vitro was relatively large for our compounds compared with available MAO inhibitors, they were not remarkably less effective in vivo. For example, pargyline is generally used at the 50 or 100 $\mathrm{mg} / \mathrm{kg}$ dosage with rats and iproniazid at the 100 $\mathrm{mg} / \mathrm{kg}$ level. We obtained strong effects with about $50 \mathrm{mg} / \mathrm{kg}$ (Fig. 2).

Comparison of the activities of the morpholino ketone (RV-378) with the morpholino alcohol (RV538) supports the idea that the carbonyl group facilitates conversion of RV-378 to a reactive species that is responsible for the MAO inhibition. Aromatic $\beta$-keto amines are known to undergo spontaneous breakdown in aqueous solution (Schönenberger et al., 1969), forming the secondary amine and the substituted acrylophenone. The latter reactive product, the formation of which might be facilitated by the active site of MAO, would be expected to react with nearby nucleophilic groups in the enzyme (Andrisano et al., 1967):
The ketone group might act additionally by facilitating binding of the inhibitor to the active site by formation of a Schiff base with an amino group.

The idea that the keto amines react covalently with the enzyme is also supported by the finding that preincubation, before substrate addition, produces greater inhibition of the enzyme (Table 1). Evidently, the inhibitor and PEA competed for entrance into the active site that has the type- $B$ specificity. In the case of the type-A reactive site, 5-HT seemed to compete effectively when the inhibitor was at a low concentration.

The failure of the keto amine to inactivate all of the MAO in the incubation tube, even with prolonged incubation without substrate (Fig. 1), could be due to spontaneous breakdown of the inhibitor in the medium followed by nonspecific reactions with various nucleophilic groups. However, another explanation is that a less easily inhibited form of MAO type B may be present in the preparation; this is indicated by the initially rapid decline in enzyme activity (Fig. 1) followed by a lower rate of decline. (A similar curve is seen in a semilog plot of the data; if a single reaction were involved, one would see a straight line.) The first phase may be due to a more sensitive form of the enzyme.

Compound R 951, the propiophenone derivative of norpethidine, resembles our keto amines in possessing a tertiary amine group at the 3-position. However, it is an analgesic and, thus, does not seem to have significant anti-MAO activity (Janssen and Van Bever, 1977). It is possible that the two bulky substituents at the distal end of the piperidine group block binding to the active site of MAO. Another similar compound, L-51988 (Murphy et al., 1978), is also an aminopropiophenone, in which the amine group is cyclopropylamine. It is active against both types of MAO, tested in neuroblastoma and platelets, particularly toward type A. This difference suggests that the long-chain acylamino group in our series is a major source of the preference for MAO type $B$ activity.

It is possible to calculate the half-life for MAO in brain with the method suggested by Price et al.

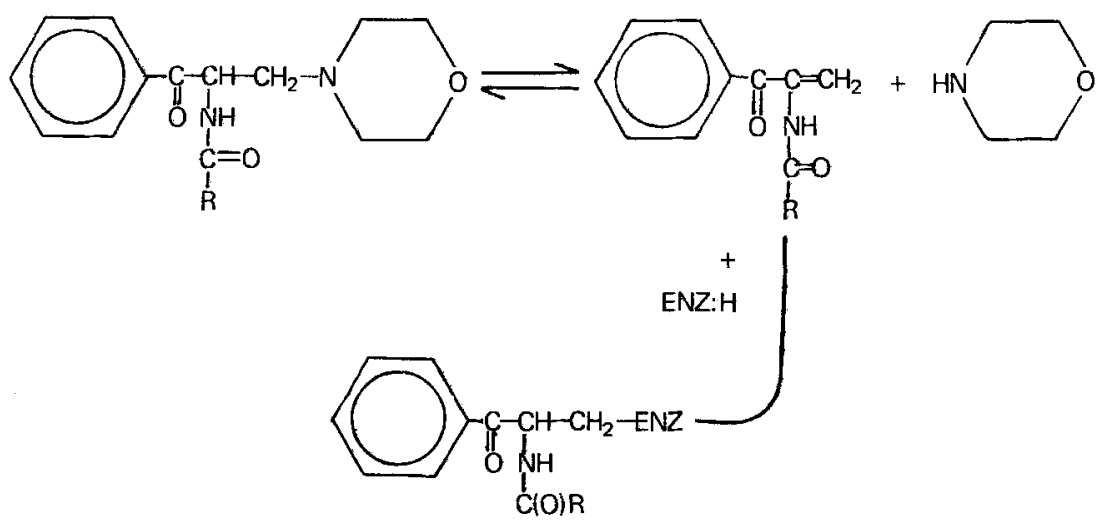


TABLE 4. Effect of mixing brain homogenates from control and inhibitor-treated mice

\begin{tabular}{|c|c|c|}
\hline \multirow[b]{2}{*}{ Brain source } & \multicolumn{2}{|c|}{ Monoamine oxidase activity ( $\mathrm{nmol} / \mathrm{h} / \mathrm{mg}$ protein) } \\
\hline & Phenethylamine & Hydrox ytryptamine \\
\hline Saline-injected control & 11.5 & 18.5 \\
\hline Drug-injected (after $1 \mathrm{~h}$ ) & 3.9 & 3.6 \\
\hline Mixture with control & $8.0(7.7)$ & $14.1(11.1)$ \\
\hline Drug-injected (after $2 \mathrm{~h}$ ) & 3.9 & 4.8 \\
\hline Mixture with control & $7.5(7.7)$ & $13.2(/ 1.7)$ \\
\hline
\end{tabular}

Mice were injected with saline or with RV-378 $(250 \mathrm{mg} / \mathrm{kg})$ and killed after 1 or $2 \mathrm{~h}$ The mixed homogenates were assayed by mixing one-half the usual amount of each. The predicted activity, shown in parentheses, was calculated by averaging the activities found with control and drug-treated homogenates.

(1962). This method, which was also used by Davis and Agranoff (1968) and by Hara and Radin (1979), is based on the assumptions that the rate of enzyme resynthesis (following its inactivation by an inhibitor) is not affected by the loss of the enzyme molecules, that the excess inhibitor is removed from the organ fairly quickly, and that the newly detected enzyme activity during the recovery period is due to the synthesis of new enzyme molecules rather than to the removal of the inhibitory moiety (perhaps by a displacement reaction). The calculated half-life for type A MAO is $13 \mathrm{~h}$, a rather rapid turnover rate. Because of the greater complexity of MAO type B (Fig. 3), this calculation is inappropriate.

When pargyline was used in the above manner to determine the half-life of brain MAO, longer halflives were obtained, using PEA and 5-HT as substrates (Maitre et al., 1976). However, when several physiological consequences of MAO inhibition were followed as a function of time, rapid recovery was observed, from which these authors concluded that a second MAO pool exists, possessing a halflife of only 12-18 h. Goridis and Neff (1971) have also observed a slow turnover rate, using the same drug and tyramine as substrate. In the case of MAO in rat liver mitochondria, Erwin and Deitrich (1971) found half-lives closer to our value: 1.8 or 3.5 days.

Squires and Lassen (1968) have pointed out that the time required for half-restoration of brain MAO is very much dependent on the nature of the "irreversible" inhibitor used. This discrepancy could be attributed to different rates of enzyme reactivation, but it could also be attributed to a variable degree of sequestering of each inhibitor in a relatively protected subcellular site and gradual release at a rate sufficient to inactivate some of the newly formed MAO molecules. The latter interpretation is supported by the finding that rats given labeled pargyline accumulated a significant fraction of the labeled material in the liver lysosomes (not a MAO site) and that the radioactivity left the lysosomes very slowly (Erwin and Deitrich, 1971). Several studies have shown that lysosomes tend to take up and store basic compounds, into which category MAO inhibitors fall.

Some of the compounds found to exhibit antiMAO activity (Table 1) are also excellent inhibitors of $\beta$-glucosidases (Hyun et al., 1975), which are apparently sensitive to some of the structural features that characterize many MAO inhibitors. However, tests with mouse liver homogenates and the prominent MAO inhibitors phenelzine and pargyline at $0.3 \mathrm{~mm}$ did not show any reciprocal inhibition of glucosidase activity.

\section{ACKNOWLEDGMENT}

This work was supported in part by a grant from the National Institutes of Health (HD-07406). We are grateful to Dr. Otto Sellinger for the use of his facilities and to Inez Mason and Pauline Arisumi for technical assistance.

\section{REFERENCES}

Andrisano R., Angeloni A. S., De Maria P., and Tramontini M. (1967) Reactivity of Mannich bases: The mechanism of the reaction between $\beta$-amino-ketones and thiophenols. $J$. Chem. Sro. [Perkin l] 2307-2311.

Christmas A. J. Coulson C. J., Maxwell D. R., and Riddell D. (1972) A comparison of the pharmacological and biochemical properties of substrate-selective monoamine oxidase inhibitors. Br. J. Pharmacol. 45, 491-503.

Davis G. A. and Agranoff B. W. (1968) Metabolic behavior of isozymes of acetylcholinesterase. Nature 220, 227-280.

Erwin V. G. and Deitrich R. A. (1971) The labeling in vivo of monoamine oxidase by [ ${ }^{4} \mathrm{C}$ ]pargyline: A tool for studying the synthesis of the enzyme. Mol. Pharmacol. 7, 219-228.

Gordis C. and Neff N. H. (1971) Monoamine oxidase: An approximation of turnover rates. $J$. Neurochem. 18, $1673-1682$.

Hara A. and Radin N. S. (1979) Destruction and resynthesis of mouse $\beta$-glucosidases. Biochim. Biophys. Acta 582, $412-422$.

Hogeboom G. H. (1955) Fractionation of cell components, in Methods in Enzymology (Colowick S. P. and Kaplan N. O., eds), pp. 16-19. Academic Press, New York.

Hyun J. C., Misra R. S., Greenblatt D., and Radin N. S. (1975) Synthetic inhibitors of glucocerebroside glucosidase. Arch. Biochem. Biophys. 166, 382-389.

Janssen P. A. J. and Van Bever W. F. M. (1977) Butyrophenones 
and diphenylbutylamines, in Psychotherapeutic Drugs (Usdin E. and Forrest I. S., eds), pp. 869-921. Marcel Dekker, New York.

Johnston J. P. (1968) Some observations upon a new inhibitor of monoamine oxidase in brain tissue. Biochem. Pharmacol. $17,1285-1297$.

Lowry O. H., Rosebrough N. J., Farr A. L., and Randall R. J. (1951) Protein measurement with Folin phenol reagent. $J$. Biol. Chem. 193, 265-275.

Maitre L., Delini-Stula A., and Waldmeier P. C. (1975) Relations between the degree of monoamine oxidase inhibition and some psychopharmacological responses to monoamine oxidase inhibitors in rats, in Monoamine Oxidase and its Inhibition (Ciba Foundation Symp. 39), pp. 247-267. Elsevier, Amsterdam.

Murphy D. L., Donnelly C. H., Richelson E., and Fuller R. W. (1978) $N$-Substituted cyclopropylamines as inhibitors of MAO-A and -B forms. Biochem. Pharmacol. 27, $1767-1769$.

Neff N. H., Yang H. Y. T., and Fuentes J. (1974) The use of selective monoamine oxidase inhibitor drugs to modify amine metabolism in brain, in Neuropsychopharmacology of Monoamines and their Regulatory Enzymes (Usdin E., ed), pp. 49-57. Raven Press, New York.

Owen F., Bourne R. C., Lai J. C. K., and Williams R. (1977) The heterogeneity of monoamine oxidase in distinct populations of rat brain mitochondria. Biochem. Pharmacol. 26, $289-292$.

Price V. E., Sterling W. R., Tarantola V. A., Hartley Jr. R. W., and Rechcigl M., Jr. (1962) The kinetics of catalase synthesis and destruction in vivo. J. Biol. Chem. 237, 3468-3475.

Schönenberger H., Bastug T., Bindl L., Adam A., Adam D., Petter A., and Zwez W. (1969) Wirkungsmechanistische Untersuchungen an antimikrobiell wirksamen $\beta$ Aminoketonen. Pharm. Acta Helv. 44, 691-714.

Squires R. F. and Lassen J. B. (1968) Some pharmacological and biochemical properties of $\gamma$-morpholino-butyrophenone (NSD 2023), a new monoamine oxidase inhibitor. Biochem. Pharmacol. 17, 369-384.

Wolfheim F. (1914) Über $\beta$-Phenyl- $\beta$-chloroathylamin. Chem. Ber. 47, 1440-1452. 